\title{
Sustainable Development Coal Mining Management (Case Study of Coal Mining Licensing Problem in South Kalimantan, Indonesia)
}

\author{
Muhammad Hadin Muhjad ${ }^{1}$, Ahmad Fikri Hadin ${ }^{1}$ and Fakhruddin Razy ${ }^{2}$ \\ ${ }^{1}$ Faculty of Law, University of Lambung Mangkurat, Indonesia \\ ${ }^{2}$ Faculty of Humanities, Sari Mulia University, Indonesia Corresponding author email: mhmuhjad@ulm.ac.id
}

\section{ABSTRACT}

Previous research has examined the sustainable development system for mining governance with the issuance of Law no. 4 of 2009 concerning Minerals and Coal hopes that mining governance based on the concept of sustainable development and eco-development will run well, but quality deterioration always occurs. On the one hand, coal mining exploitation activities can provide economic benefits and on the other hand, cause negative impacts in the form of damage and pollution to the environment so as to result in losses to local governments and the community. To control and organize good mining with a licensing system, a concept of sustainable development policy through technological engineering has been developed. The article uses normative legal research through a statutory approach and a case approach in discussing the coal mining crisis in South Kalimantan. The results of the study as new findings in this article found that the concept of sustainable development, which is a government policy in the context of exploiting coal mines, has not been able to reduce the negative impacts arising from mining activities. The issued mining exploitation permit for coal mining in South Kalimantan caused rejection by the people because even though mining activities were carried out through technological engineering in order to pursue economic growth, it was also unable to solve the increasingly serious devastating environmental problem as happened in South Kalimantan Province.

KEY WORDS: MANAGEMENT, COAL MINING, SUSTAINABLE DEVELOPMENT.

\section{INTRODUCTION}

George W Rock Pring stated that "two very significant developments are occurring in the mining industry and related government resource programs worldwide. One is positive, the other problematic. Working together, these two trends have the potential to change dramatically the way in which mineral resource companies, the Governments of resource-based economies, and indeed the world function in the 21st century". One of the greatest challenges facing the world today is the integration of economic activity with the environment, social concerns,

Biosc Biotech Res Comm P-ISSN: 0974-6455 E-ISSN: 2321-4007

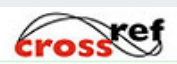

Identifiers and Pagination

Year: 2021 Vol: 14 No (5) Special Issue

Pages: $162-170$

This is an open access article under Creative

Commons License Attribn 4.0 Intl (CC-BY). DOI: $h t t p: / / d x . d o i . o r g / 10.21786 / b b r c / 14.5 / 30$ and an effective system of government. This is in line with the philosophical doctrine of Pancasila which aims to prosper the people by living a balanced, harmonious and harmonious life which is stated in legislation as law so that environmental integration, social care and government systems are effective.

In the field of exploiting natural resources, it is not carried out solely for economic purposes but must also be integrated with environmental preservation, social awareness and effective governance. One of the potential natural resources in Indonesia, especially in South Kalimantan Province, is the natural resource of coal. The Indonesian Coal Mining Association states that coal production in 2006 was around 193.54 million tons, of which 145 million tons were exported to Asia, Europe and other countries. Then in 2007, national coal production reached 225 million tons, of which 150 million tons will be exported. Data in 2007 also shows
Article Information

Received: $25^{\text {th }}$ Jan 2021 Accepted after revision: $28^{\mathrm{h}}$ Mar 2021 
that Indonesia has coal resources of 90 billion tons and reserves of 18.7 billion tons that can be used for at least 110-120 years. Indeed, one side has a positive value to meet domestic and foreign energy needs and as an Indonesian coal export commodity that continues to increase, this is also the case with South Kalimantan which is the second largest contributor to national coal after East Kalimantan.

The potential of natural resources in the form of coal mines owned by the South Kalimantan area is quite large with good quality and its existence is almost spread throughout the districts (Banjar, Tanah Laut, Kotabaru, Tanah Bumbu, Hulu Sungai Tengah, Hulu Sungai Utara, Hulu Sungai Selatan, Tapin and Tabalong ). So that in some areas, the mining sector has become a mainstay sector in increasing local revenue. However, on the other hand, there is a problem, namely because it is a non-renewable resource, meaning that once dredged mining material will not recover to its original state. Exploitation of mineral resources that does not comply with good mining principles does not provide benefits to the government or society.

Quoting data from the Central Statistics Agency (BPS) of Tanah Bumbu Regency and the Office of Investment and One Stop Services (PMTSP) of South Kalimantan Province, out of 160 companies that have Mining Business Permits (IUP) in South Kalimantan which produced 61,717,236 tons of coal. The largest portion is produced by Tanah Bumbu Regency with 24,312,169 tonnes, or around nearly 40 percent of the total production of all IUP holders in South Kalimantan.

As a province that is rich in natural resources, especially mining products, South Kalimantan (Kalsel) is also inseparable from environmental problems. Of a number of mining companies operating in this province, not all companies, both large and small, are willing to take responsibility for improving the environmental area in which they operate. In fact, quite a number of excavated ex-mining locations are not closed by mining companies. Although there is no definite data on the number of victims in South Kalimantan Province as a result of this, referring to JATAM data, it appears that South Kalimantan Province is the second province that has the most mining holes in Indonesia after East Kalimantan Province, with 814 mine pits. The mining pits are spread across eight districts. The largest mining hole is in Tanah Bumbu Regency with 264 mine pits, followed by Tanah Laut Regency with 223 mine pits, and followed by Banjar Regency with 117 mining holes.

Therefore, Law no. 4 of 2009 concerning Mineral and Coal Mining which replaced Law No.11 of 1967 concerning Mining Principles as a basis for exploitation of mineral and coal resources designed to pursue economic growth without damaging the environment. This is as stated in Article 3 of Law no. 4 of 2009 that in order to support sustainable national development, the objective of mineral and coal management is in letter e to increase the income of local, regional and state communities, and to create jobs for the greatest welfare of the people. Article 4 paragraph (1) Law no. 4 of 2009 has recognized that Minerals and coal as non-renewable natural resources are national assets controlled by the state for the greatest welfare of the people.

So there are two opposing sides, namely some that are beneficial for the welfare of the people and there are also those that are detrimental because coal is a non-renewable natural resource, thus it is vulnerable to environmental damage. Even so, generally coal producing regions still take alternatives to utilize coal mining to support their economy. Indeed, there are one or two regions that do not tinker with these natural resources, such as the Hulu Sungai Tengah Regency by the Regional Government and its people, but the central government actually grants mining business permits to a company, but on the other hand there are also local governments that have given mining business permits withdrawn on the grounds that it can damage the environment.

\section{RESEARCH METHODS}

The research method used in this paper is normative legal research, which examines the issue of coal mining from a legal perspective in depth on the established legal norms. The approach taken in this writing is a statutory approach, this approach is to clarify issues concerning the consistency of the philosophical basis, ontological basis and ratio legis / legal logic regarding the concept of sustainable development in the Mineral and Coal Law. And the case approachin discussing the turmoil of coal mining in South Kalimantan.

\section{ANALYSIS AND DISCUSSION}

Legal Basis For Mining Management: So far, we can review the impact of mining on the environment from two aspects, namely positive and negative impacts. The positive impact, be it coal, gold or diamond mining activities carried out by the people can increase the income and standard of living of the community and create jobs. The negative impacts of mining activities are as follows:

a. Damage to the landscape due to ponds / hole basins that were not reclaimed.

b. The source of water pollution is both high turbidity levels and mercury content in gold mining by the people.

c. Causes of erosion and sedimentation, as well as damaging watersheds and water systems.

d. The occurrence of wasteful use of mineral resources.

e. Prone to mining accidents.

f. Threatens forest and aquatic ecosystems.

g. There is no entry of state revenue.

h. Inhibiting the entry of private sector investment.

i. In mining areas the people are generally prone to security stability. 
With the enactment of Law Number 4 of 2009 concerning Mineral and Coal Mining, the contract regime has changed to a licensing regime.Changes in the status of the Contract of Work (KK) and Coal Mining Concession Work Agreement (PKP2B) into Mining Business Permits will make the government the absolute owner of natural resources and public law applies, where the licensor, namely the government, can at any time revoke mining business permits according to sanctions. sanctions made based on law. The positive impact, the status of KK / PKP2B to become IUP is that the change in working relationship with the contract regime will end up becoming a licensing regime. This means that it is no longer a civil relationship, but the absolute government as the owner of natural / mineral resources in accordance with Article 33 of the 1945 Constitution.

In Law no. 4 of 2009 that the Coal Mining Concession Work Contract and Work Agreement must be changed to a Special Mining Business License within 1 year from the enactment of the Law. Even in Law no. 3 of 2020 concerning amendments to Law No.4 of 2009 still provides guarantees for these KK and PKP2B. Implementing regulations of Law no. 4 of 2009 is PP No. 22/2010 concerning Mining Areas and PP No. 23/2010 concerning the Implementation of Mineral and Coal Mining Business Activities with four changes, PP No. 24 of 2012, PP. 1 of 2014 concerning the second amendment, PP. 77 of 2014 concerning the Third Amendment, PP. 1 of 2017 then PP No. 55 of 2010 concerningGuidance and Supervision of the Implementation of Mineral and Coal Mining Business Management. On the basis of Law No.4 of 2009 and its implementing regulations are in order ensure the effectiveness of the implementation and control of mining business activities in an efficient, effective and competitive manner, so there are several principles to be adhered to, namely:

1. Principles of Mining Area auction. There is a provision on the auction of mining areas, in which every company or party that will carry out mining exploitation, especially coal, in order to obtain a mining permit must go through an auction process. This method is seen as a progress in the national mining business world. There are several advantages to the licensing system through the auction mechanism, namely:

a. $\quad$ Pressing the emergence of a mining permit mafia. There is a practice of buying and selling mining permits carried out by certain individuals who only pay a fee for permits to obtain a number of permits, but not for business, but for resale. The auction mechanism is expected to be effective in suppressing the practice of buying and selling mining permits that have been happening so far. There is a practice of buying and selling mining permits, not a few parties who originally intended to do business in the mining sector have become victims of a large number of financial frauds.

b. Filter media. Only companies that are really ready financially, and really intend to carry out mining business activities will participate in the auction process, so the auction mechanism is a natural process for companies that only intend to experiment or only act as license brokers.

c. Increase State income. Through an auction, the State will receive two benefits at the same time, firstly, obtaining revenue for the State treasury, second, obtaining a qualifying company that is ready to carry out mining business activities.

d. More accommodating, namely by the inclusion of regulations that favor the interests of the people,

e. The strategic technical considerations of a mining material are more determined based on considerations of national interests, not on the type of minerals. That is, whether a mining material is technically, economically, in interest, and in terms of state defense and security, its existence is strategic and vital, then management becomes the authority of the State / Government.

f. There is a clear division of management authority between each government action.

g. There is an integrated management effort, from exploration to post mining.

In line with that, in accordance with what is stated in the general explanation of Law No.4 of 2009 is trying to accommodate the problems that have been developing, as well as adjusting to the development of changes in mining development, both National and International. The thought of accommodation of problems and developments is contained in the following main points of thought:

1. Minerals and coal as non-renewable resources are controlled by the State and their development and utilization are carried out by the government and local governments together with business actors.

2. The government then provides opportunities for business entities with Indonesian legal status, cooperatives, individuals, and local communities to carry out mineral and coal exploitation based on permits, which are in line with regional autonomy, granted by the government and / or local governments in accordance with their respective authorities.

3. In the context of implementing decentralization and regional autonomy, the management of mineral and coal mining is carried out based on the principles of externality, accountability and efficiency which involve the government and regional governments.

4. Mining businesses must provide economic and social benefits for the maximum welfare of the people.

Problematic Mining Business Permit Issuance Cases: This case started when the Minister of Energy and Mineral Resources (ESDM) issued Decree No. 441.K / 30 / DJB / 2017 dated 4 December 2017 concerning the 
Adjustment of the Phase of the Coal Mining Exploitation Work Agreement (PKP2B) of PT Mantimin Coal Mining (MCM) to the Production Operation Activity Stage, covering three locations in Hulu Sungai Tengah Regency (HST), Balangan and Tabalong with a total area of 5,908 hectares. for mining in the area of Hulu Sungai Tengah Regency covering East Batangalai District. Mining Business License (IUP) is valid until 2034.

The issuance of the IUP from the Minister of Energy and Mineral Resources has drawn criticism from the wider community. The reason is for the Hulu Sungai Tengah Regency Government (HST) itself considers something strange because there has never been a process in the HST Regency Government, suddenly the IUP of the Minister of Energy and Mineral Resources appears, and for the public they consider the issuance of this IUP from the Minister of Energy and Mineral Resources threatens the preservation of the natural environment of HST Regency surrounding areas. So that there was a wave of rejection from various walks of life.

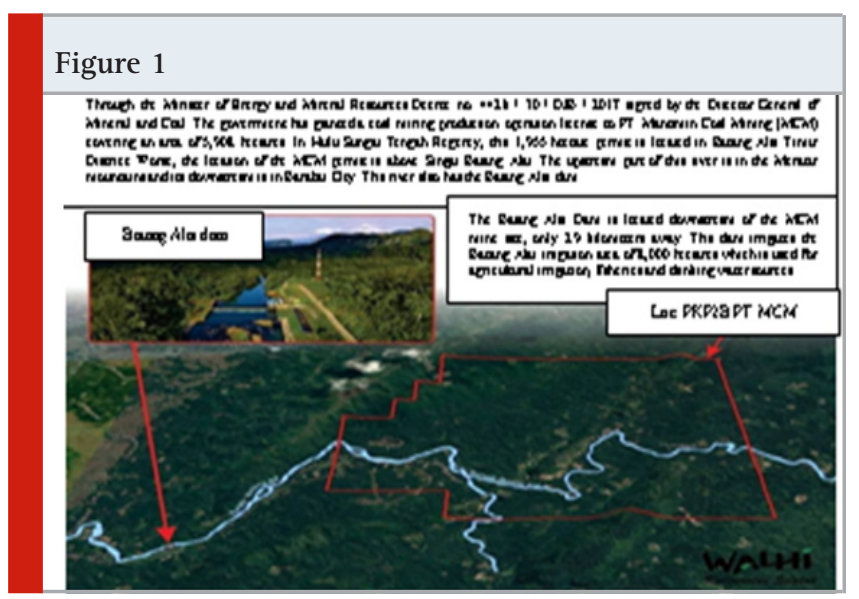

In the IUP crisis of the Minister of Energy and Mineral Resources, there was a controversial statement from the Director General of Mineral and Coal of the Ministry of Energy and Mineral Resources, Bambang Gatot Ariyono, who emphasized that even though the Minister of Energy and Mineral Resources has issued Decree No. Mantimin Coal Mining (MCM) Becomes a Production Operation Activity Stage, but there is no environmental impact analysis (Amdal), so companies are not allowed to carry out production operations or mining activities. There are only Amdal in the Tabalong Regency area. while in HST it does not have an Amdal, so the company is not allowed to carry out mining. The head of the South Kalimantan (South Kalimantan) Environment Agency, Ikhlas Indar, has not yet made an EIA for coal mining activities, Ikhlas Indar, that PT MCM's Amdal document for carrying out production operations in the HST Regency was not issued. so that the company cannot operate. There has indeed been an EIA submission since 2010, but it has not been endorsed by his party. This is also related to the reason that the river there is the intake of the PDAM, so it is feared that the river water resources there will be polluted due to mining.
What's interesting about this case is in Law no. 32/2009 concerning Environmental Protection and Management states that business permits are issued after being granted an environmental permit, while environmental permits are issued after EIA approval. Thus the statement by the Director General of Mineral and Coal at the Ministry of Energy and Mineral Resources Bambang Gatot Ariyono that there is no Amdals yet but issuing an IUP means that the Minister of Energy and Mineral Resources violates Law No. 32 of 2009 which can qualify as a criminal offense (Article 101 of Law No. 32 of 2009).

The Department of Energy and Mineral Resources of South Kalimantan Province gathered a number of parties who contravened the coal mining exploitation plan of PT Mantimin Coal Mining (MCM) in Hulu Sungai Tengah Regency. The Ministry of Energy and Mineral Resources of South Kalimantan invited the South Kalimantan Forum for the Environment, Dayak Kalimantan Bersatu, and other technical agencies. On that occasion the Head of the Mineral and Coal Sector of the Ministry of Energy and Mineral Resources of South Kalimantan, Gunawan Harjito, said that the Ministry of Energy and Mineral Resources had already issued an Amdal permit, an Environmental Management Plan, and an Environmental Monitoring Plan on 26 December 2000. These three permits were signed directly by the Secretary General of the Ministry of Energy and Mineral Resources at that time, Djoko Darmono.

This environmental permit applies to the PT MCM PKP2B working area in Tabalong and Hulu Sungai Utara Districts (currently part of it is part of Balangan Regency), namely the Upau Block covering an area of 4,545 hectares. Quoting a copy of the letter, the process of transporting coal from the Upau Block passes through a special dock in Paser Regency, East Kalimantan. The Amdial Permit at that time was sectoral from the Ministry of Energy and Mineral Resources Number 537/26 / SJN.T / 2000, while for the Batutangga Block in HST Regency covering an area of 1,964 hectares, PT MCM has not yet obtained an EIA permit because the South Kalimantan Provincial Government has never issued an EIA permit . The chronology and the results of the decision from the first level to the cassation will be explained using the table below along with the picture of the dispute area:

The legal considerations of the Supreme Court cassation panel of judges are more to the facts and conditions in South Kalimantan, which have karst areas, must be protected. The judge assessed that some of the MCM mining areas are located in karst areas as geological protected areas. If this area is exploited, it has the potential to damage the function of the natural aquifer, which functions as a reservoir and channel of water for the surrounding area. And when PT. MCM can take external legal measures, namely through the mechanism of reconsideration to the Supreme Court, the Supreme Court reaffirms the cassation decision on the grounds that the environmental damage was severe if this permit was granted. The case of PT. Mantimin 
Coal Mining (PT. MCM), of course, the attraction of the central and regional authorities in relocating the governance of natural resource permits still needs to be studied empirically. In fact, the evaluation of regional authority in natural resource management has not yet been completed as stipulated in the Regional Government Law, Law Number 3 of 2020 concerning Amendments to the Minerba Law (the new Minerba Law) has been reenacted, which draws mineral and mining governance to the center like the model in the New Order era.

Table 1 . The area of the permit being contested Source: Walhi South Kalimantan

\begin{tabular}{|c|c|}
\hline Legal effort & The result \\
\hline $\begin{array}{l}\text { February 28, 2018, Walhi sued SK number 441.K / } 30 \text { / } \\
\text { DJB / } 2017 \text { at the Jakarta State Administrative Court. } \\
\text { After that the trial took place and was scheduled. } \\
13 \text { July } 2018 \text { a local examination was carried out } \\
\text { with the Jakarta State Administrative Court Judge, } \\
\text { Walhi, and the Nateh Village Community, } \\
\text { Hulu Sungai Tengah. The ESDM } \\
\text { Ministry and PT. MCM was not present at the trial. }\end{array}$ & $\begin{array}{l}\text { October 22, 2018, the Jakarta Administrative } \\
\text { Court decided on the lawsuit by Niet Ontvankelijke } \\
\text { Verklaard (NO). The judge stated that it was } \\
\text { not the PTUN's authority to try case number } \\
47 . \text { Even though the trial had } \\
\text { been going on for eight months. }\end{array}$ \\
\hline $\begin{array}{l}\text { November 2, 2018, after the Jakarta Administrative } \\
\text { Court decided N0 for the lawsuit against SK } \\
\text { number } 441 . K \text { / } 30 \text { / DJB / 2017. Walhi filed an } \\
\text { appeal to the Jakarta State Administrative } \\
\text { High Court (PTTUN). }\end{array}$ & $\begin{array}{l}\text { March 20, 2019, PTTUN Jakarta decided to reaffirm } \\
\text { the decision of the Jakarta State Administrative Court } \\
\text { number } 47 \text { / G / LH / } 2018 \text { / PTUN-JKT dated } \\
22 \text { October 2018. With a decision letter } \\
\text { dated March 14, } 2019 \text { number } \\
28 \text { / B / LH / } 2019 \text { / PT.TUN.JKT. }\end{array}$ \\
\hline $\begin{array}{l}\text { April 2, 2019, Walhi registered an appeal } \\
\text { to the Supreme Court on the Jakarta PTTUN } \\
\text { decision number } 28 \text { / B / LH / } 2019 \text { / } \\
\text { PT.TUN.JKT dated March 14, } 2019 .\end{array}$ & $\begin{array}{l}\text { October } 15,2019 \text {, the Supreme Court decided } \\
\text { to grant the cassation, according to the } \\
\text { publication on their website, the verdict } \\
\text { reads cassation, canceled judex facti, } \\
\text { adjudicated the lawsuit itself, canceled } \\
\text { the object of the dispute. The object of } \\
\text { the dispute being sued is SK ESDM } \\
\text { number } 441 . \mathrm{K} / 30 \text { / DJB / } 2017 \\
\text { concerning the granting of a coal } \\
\text { mine production operation permit for PT MCM. }\end{array}$ \\
\hline
\end{tabular}

Figure 2: Source: Walhi South Kalimantan

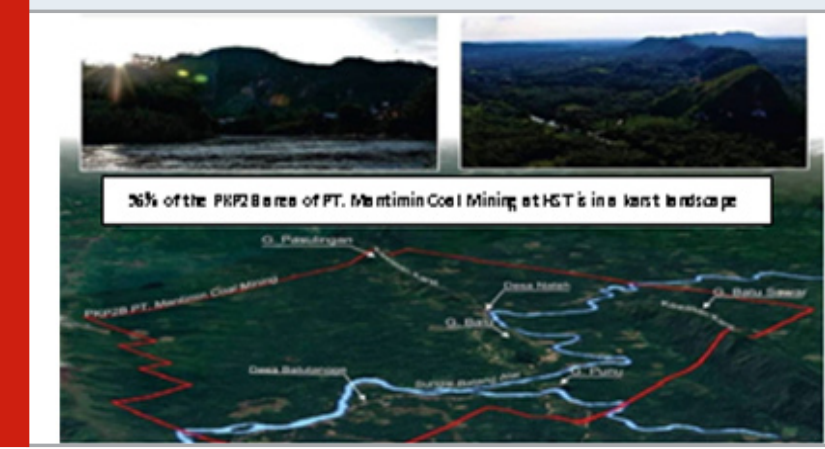

The Case of Problematic Mining Business License Revocation: The Governor of South Kalimantan, Sahbirin Noor, has revoked 425 Mining Business Permits (IUP) from a total of 789 IUPs as a result of the evaluation of the Ministry of Energy and Mineral Resources in the mining sector in South Kalimantan Province. It is estimated that the number of healthy mining companies that meet the government's clean and clear $(\mathrm{CnC})$ requirements is only 100 companies. Furthermore, this revoked mining permit area will be turned into a mining area through an auction mechanism.

In addition, to restore the post-mining area of the hundreds of IUPs, the South Kalimantan Provincial Government will also demand the withdrawal of the reclamation guarantee fund from the Regency Government or the company if it has not been paid to the local government. His party will implement the obligation to pay royalties and other obligations of the company before the coal is shipped. It is recorded that royalty funds deposited to the state treasury after the IUP control policy reached Rp. 6 trillion. This amount is almost the same as the amount of royalties collected from hundreds of mining companies before IUP control. The case that attracted public attention was South Kalimantan Governor Sahbirin Noor revoked the coal mining business license (IUP) of three subsidiaries of PT Sebuku Iron Lateritic Ores (SILO) Group, in the Pulau 
Laut area, Kotabaru Regency. There are 3 Decrees of the Governor of South Kalimantan regarding the revocation of IUP Production Operations, namely:

1. South Kalimantan Governor Decree No. 503/119 / DPMPTSP / 2018 dated 26 January 2018 the revocation of IUPOP for PT Sebuku Batubai Coal covering an area of 5,140 ha in Pulau Laut Utara and Pulau Laut Tengah Districts

2. South Kalimantan Governor Decree No. 503/120 / DPMPTSP / 2018 dated 26 January 2018, revocation of IUPOP for PT Sebuku revocation of IUPOP for PT Sebuku Sejaka Coal covering an area of 8,140 ha in Pulau Laut Timur District.

3. South Kalimantan Governor Decree No. 503/121 / DPMPTSP / 2018 dated 26 January 2018, the revocation of IUPOP for PT Sebuku Tanjung Coal covering an area of 8,990 ha in Pulau Laut Utara and Pulau Laut Tengah Districts.

The reasons for the revocation of the IUP, apart from the results of academic studies, were also driven by the aspirations of various elements of the Kotabaru community who strongly objected to the existence of mining on Laut Island and Kotabaru Regent Regulation Number 30 of 2004 concerning the prohibition of coal mining activities on Pulau Laut, Kotabaru Regency which was published by the Regent. H. Sjachrani Mataja on December 29, 2004, as well as recommendations from the leadership of Muhammadiyah Kotabaru in 2010, and the Community Communication Forum for the Sea Island Rescue Movement of Kotabaru Regency on November 30, 2014 , to groups of fishermen and fish traders.

After various demonstrations and the rejection of mining on Pulau Laut grew tighter, the Provincial Government of South Kalimantan together with the Chairperson and Deputy Chairperson of the Kotabaru DPRD and the Kotabaru Regency Government held a meeting on September 13, 2017 which basically supported and recommended the Pulau Laut without coal mining. Agus Andriono, The chairman of the NGO, Gepak Kotabaru, approved the South Kalimantan Governor's decision to revoke the Coal Production Operation Mining Business License (IUPOP) belonging to PT. SILO Group, because in addition to the impact of natural damage that will be caused, this will certainly trigger horizontal conflicts, between people who are pro and contra about the existence of coal mining activities on the sea island. We will of course continue to oversee this decree and ensure that mining activities carried out by PT. SILO Group has completely stopped and Mining Free Sea Island is a reality.

Sjachrani Mataja, the former Regent of Kotabaru who issued the IUP, emphasized that at the time of issuing the IUP there was an MoU between PT. SILO Group with the Regent of Kotabaru that the issuance of IUP is required, among others, to build a bridge between Pulau Laut and Kalimantan Island, not selling coal outside, and others, it turns out that this agreement was not kept by PT. SILO. However, PT. SILO argued that it had been amended at the time of Regent Irhamni. Managing Director of PT SILO Hendry Yulianto said the agreement amended at the time of Regent Irhami Ridjani was legitimate, because the regional head who made the agreement represented the regional government. Meanwhile, Director of Walhi Kisworo Dwicahyono said that if the agreement is changed, the company's Production IUP in Pulau Laut will be canceled. But strictly speaking, the agreement is actually odd, Finally this case was resolved through the State Administrative Court through decision number 5 / G / 2018 / PTUN.BJM which granted the Plaintiff's Lawsuit in its entirety, Declaring the Decree of the Governor of South Kalimantan Number 503/121 / DPMPTSP / 2018 concerning the Revocation of Mining Business Permit for Coal Production Operations PT. Sebuku Tanjung Coal in Kotabaru Regency (KTB. 1007IUP0P0095) dated January 26, 2018. Seta obliged the Defendant to revoke the Decree of the Governor of South Kalimantan Number 503/121 / DPMPTSP / 2018 concerning the Revocation of the Coal Production Operation Mining Business Permit of PT. Sebuku Tanjung Coal in Kotabaru Regency (KTB. 1007IUPOP0095) dated January 26, 2018.

Coal Mining and Sustainable Development: Many questions arise in the community whether coal mining activities cannot meet the standards of sustainable development as referred to in the concept of Our Common Future by the World Commission on Environment and Development, 1987, namely development that can meet the needs of the present generation without sacrificing the ability of future generations to meet their needs, which is operationally poured out through the control instrument in licensing.

Legally, historically, MPR Decree No. IV / MPR / 1999 regarding the 1999-2004 GBHN explains the condition of natural resource management that "the concept of sustainable development has been put in place as a policy, but in practice so far, natural resource management is uncontrolled with the result of environmental destruction that disturbs conservation. natural; This expression shows the recognition from the highest institutions of our country that the sustainable development in the management of natural resources has not yet been carried out. The same is stated in the preamble to MPR Decree No. IX / MPR / 2001 which states that the ongoing management of agrarian / natural resources has resulted in a decrease in environmental quality, inequality in the structure of control, ownership, use and utilization as well as causing various conflicts. Then it is also stated that the laws and regulations relating to the management of agrarian or natural resources are overlapping and contradicting each other.

Thus the management of coal natural resources has not met the standards of sustainable development, even Sonny Keraf stated that why the paradigm does not work, especially why ecological crises continue to occur, because this paradigm reaffirms the ideology of developmentalism. What was accomplished at the Earth Summit in Rio de Janeiro ten years ago, is nothing but a compromise proposing redevelopment, with the main 
focus being economic growth. As a result, during the last ten years, there have not been many changes experienced by all countries in the world in order to correct their economic development which remains the same, namely control and exploitation of natural resources with all their negative impacts on the environment, both damage to natural resources and environmental pollution. Even though sustainable development is at its lowest point, according to Martin Khor, there are also signs of its revival as a paradigm. The limitations and failures of globalization have caused negative reactions from some parts of the community which in turn may have an impact on changes in a number of policies. With the emergence of pro-sustainable development forces in governments in developing countries (NSB), they have become more aware of their rights and responsibilities to rectify various problems that exist today, including changing a number of regulations in the WTO. The World Summit On Sustainable Development-WSSD (World Conference on Sustainable Development) provides an excellent opportunity to refocus people's attention and strengthening efforts.

In relation to the implementation of sustainable development in Indonesia, the assessment of D. Pearce \& G Atkinson should be noted in their writing "A Measure of Sustainable Development". The two authors assess that Indonesia's development is still not sustainable. This is because the depreciation of Indonesia's natural resources is $17 \%$ of the GDB, while the investment is only $15 \%$. Development is only considered sustainable in utilizing natural resources through technological engineering and art, so that if we consume added value, it is possible to save $17 \%$ or even more for an investment. So it is clear that the ability of human resources to provide "added value" to development support resources through the application of science, technology and art is the key to whether the development being carried out is "sustainable" sustainable, sustainable or not.

Thus, even though formally it is clear that the development carried out in Indonesia must be in the form of Sustainable Development and Environmental Friendly but still only in the form of das solen and through legal instruments it is hoped that it can be realized at the basic sein level. However, this success still depends on many factors, apart from juridical, political and cultural factors, including the condition of the human resources who are responsible for it. It is an irony in modern times like today in our country, Indonesia, a country that is rich in energy sources where electricity is still out. The abundance of Indonesia's natural wealth is not managed properly and responsibly, which makes the population of this country poor. In fact, this natural wealth has become a natural resource curse (Resources Curse) and cannot be enjoyed cheaply / for free by the people who are mostly poor.

Just look at the fact that not all people have easy access to energy sources.Exploiting natural resources on the pretext of development is not the welfare received by the people, but rather the suffering felt by the people. The wealth of natural resources that are owned and contained in the bowels of the Indonesian earth which are abundant and of various types is a gift that should be grateful and of course maintained continuously from irresponsible human greed and his mind only wants to exploit it without considering sustainability and environmental harmony. The choice of our Government by exploiting natural resources to finance development is a wrong choice. We all know that coal SDA is a nonrenewable resource, which one day will run out and at the same time bring severe environmental damage. D. Pearce \& G Atkinson D. Pearce \&t G Atkinson wrote that the negative impacts of natural resource exploitation can be avoided if engineering technology is used. This opinion which I disagree with. How can an environment that was destroyed by exploitation be returned either by technological engineering or by technological engineering the exploitation of natural resources does not destroy the environment. Evidence has shown that technology has not been able to restore nature to what it used to be due to exploitation.

Pay close attention to what happened in South Kalimantan Province in ex-mining areas, based on the Greenpeace research report that the extensive coal mining activity in South Kalimantan Province is because one third of South Kalimantan has become a coal mining area. has damaged water sources, endangers the health and future of local communities as well as strong evidence that coal mining companies have dumped hazardous waste into rivers and community water sources, violating national standards for waste disposal in mining. All samples taken were also detected to contain heavy metal concentrations. Leakage and the potential overflow of water from ponds contaminated with hazardous waste in coal mining concessions pose a danger to surrounding swamps, creeks and rivers.

In this regard, Greenpeace issued several recommendations and demands. First, coal mining companies that profit from dirty and illegal mining activities, must be legally and morally responsible for restoring the environment from their illegal activities, for reducing waste from water bodies, or the company's license must be revoked. Second, companies found to have broken the law must be held responsible for financing cleanup operations, even if their mining permits are completed or revoked, because the acid mine drainage problem will persist for decades.

The government must not give a coal mining company a "license to poison" the environment and people of South Kalimantan. Third, The relevant government authorities must monitor and carry out more in-depth investigations of coal mining companies that violate national standards, and pollute the environment. Law enforcement must be tightened, sanctions must be tightened, and regulatory loopholes must be closed. Therefore, proper management of sustainable coal mining needs to be implemented by taking into account: 
1. In terms of limited quantity and quality of coal sources,

2. Location of coal mining and its influence on community growth and regional development,

3. Environmental carrying capacity and

4. Environmental, economic and social impacts of the community due to the coal mining business.

The research results show that the sustainability score, for the social and environmental dimensions, is still below the sustainability score, for the economic dimension it is above the sustainability score. Viewed in the field, it can be said that the impact of environmental damage due to coal mining activities is very worrying even though $\mathrm{PAD}$ and the economy of the communities around the mine have increased. However, when measured from its prospective analysis, it can be concluded that coal mining activities are more detrimental to both material and non-material things to the community in general from environmental damage such as floods, air pollution, water and soil. Therefore Hardin suggests "so the tragedy of the commons as a cesspool must be prevented by different means, by coercive laws or taxing devices that make it cheaper for the polluter to treat his pollutants than to discharge them untreated.

\section{CONCLUSION}

Coal mining has two sides, one side provides economic benefits and the other side has a negative impact on the environment which results in losses for local governments and society. Controlling coal mining through licensing instruments has not been able to direct mining activities that provide economic as well as environmental benefits to the government and surrounding communities. The concept of sustainable development, which is a government policy in the context of exploiting coal mines, has not been able to reduce the negative impacts arising from mining activities. Serious environmental damage has occurred in South Kalimantan Province due to coal mining activities.

\section{REFERENCES}

Abdurrahman. Pembangunan Berkelanjutan Dalam Pengelolaan Sumber Daya Alam Indonesia. Makalah disampaikan pada Seminar dan Lokakarya Pembangunan Hukum Nasional VIII BPHN Departemen Kehakiman dan HAM di Denpasar Bali. 2003.

Badan Pusat Statistik (BPS) Tanah Bumbu. Produksi Batubara Perusahaan Pemegang Izin Usaha Pertambangan Operasi Produksi (Iup-0p) Menurut Kecamatan Lokasi Penambangan Di Kabupaten Tanah Bumbu 2015. 2020.

Dinas Penanaman Modal dan Pelayanan Terpadau Satu Pintu (PMTSP) Kalsel. Potensi Pertambangan, DPMTSP. 2020. Accessed on: https://dpmptsp.kalselprov.go.id/ potensi-pertambangan

Garrett Hardin on Wartiningsiha, and Nunuk Nuswardania, Policy Model Reconstruction of Social
Forestry, Sriwijaya Law Review, 1.2 (2017), 110

George W Rock Pring. International Law and Mineral Resources dalam Mining, Environment and Development, A series of paper prepared for the United Nations Conference on Trade and Development (UNCTAD). UNCTAD. 1997.

Greenpeace. Beberkan Skandal Perusahaan Tambang Batubara Racuni Penduduk. Accessed on: https://www. tribunnews.com/nasional/2014/12/03/greenpeacebeberkan-skandal-perusahaan-tambang-batubararacuni-penduduk

Greenpeace. Sumber Air di Kalsel Tercemar Limbah Batu Bara. Accessed on: https://www.tambang.co.id/ greenpeace-sumber-air-di-kalsel-tercemar-limbahbatu-bara-1685/

Greenpeace. Tambang Batubara Meracuni Air di Kalimantan Selatan. Accessed on: https://issuu.com/ greenpeacesea-indonesia/docs/praktik_tambang_ batubara_meracuni_

Hadin, Ahmad Fikri \& Natosmal Oemar, Erwin. Problematika Tata Kelola Sumber Daya Alam dan Tantangan Penegakan Hukum Sektor Sumber Daya Alam di Kalimantan Selatan, Kertas Kerja 5/2020, Auriga Nusantara. Jakarta. 2020.

Holijah, Strict Liability Principle: Consumer Protection from Hidden Defective Products in Indonesia. Sriwijaya Law Review 2020;1(4):110.http://dx.doi.org/10.28946 / slrev.Vol4.Iss2.295.pp 109-123

Keraf, Sonny A. Etika Lingkungan. Jakarta: Penerbit Buku Kompas. 2002. Page: 167-168

Kridangkara, Whisnupaksa. 143 Anak Mati Sia-sia di Lubang Tambang. 2019. Accessed on: https:// www.solopos.com/143-anak-mati-sia-sia-di-lubangtambang-979216

Kumparan. Dinas ESDM Kalsel Sepakat Menggugat Kementerian ESDM. 2018. Accessed on: https:// kumparan.com/banjarhits/dinas-esdm-kalsel-sepakatmenggugat-kementerian-esdm/full

Kumparan. Waduh, Kementerian ESDM yang terbitkan Amdal PT MCM. 2018. Accessed on: https://kumparan. com/banjarhits/waduh-kementerian-esdm-yangterbitkan-amdal-pt-mcm

Michael Tost et al.The state of environmental sustainability considerations in mining. Journal of Cleaner Production 2018; 182:969-977, https://doi. org/10.1016/j.jclepro.2018.02.051

Moh. Soerjani. Lingkungan: Sumberdaya Alam dan Kependudukan dalam Pembangunan., Jakarta: UI Press. 1997. page: 66-67

Mongabay. Daerah Bulat Tolak Tambang Batubara MCM, Walhi Gugat Menteri karena Keluarkan Izin Produksi. Accessed on: https://www.mongabay.co.id/2018/03/09/ daerah-bulat-tolak-tambang-batubara-mcm-walhi- 
gugat-menteri-karena-keluarkan-izin-produksi/ Mongabay. Walhi Menangkan Gugatan di MA: Rencana Eksploitasi Mantimin Mining di Meratus Batal. 2021. Accessed on: https://www.mongabay. co.id/2021/02/23/angin-segar-penyelamatanmeratus-mahkamah-agung-patahkan-upayamantimin-coal-mining/\#: : text=Walhi \% 20 Menangkan\%20Gugatan\%20di\%20MA \%3A\%20 Rencana \% 20 Eksploitas i \% $20 \mathrm{Mantimin} \% 20$ Mining\%20di\%20Meratus\%20Batal,-oleh\%20 Della\%20SyahniEttext=Mahkamah\%20Agung\%20 memenangkan\%20Walhi\%20atas,Mantimin\%20 Coal\%20Mining\%20(MCM).

Muhjad M Hadin. Hukum Lingkungan Sebuah Pengantar Untuk Indonesia, Cetakan 1. Yogyakarta: Genta Publishing. 2015.

Muhjad M. Hadin. Penelitian Hukum Indonesia Kontemporer, Cetakan 1. Yogyakarta: Genta Publishing. 2012.
Sudrajat, Nanang. Teori dan Praktik Pertambangan Indonesia Menurut Hukum. Jakarta: Pustaka Justisia. 2010.

Undang-Undang Republik Indonesia Nomor 4 Tahun 2009 Tentang Mineral dan Batu Bara

Walhi Kalsel. Lubang Tambang Pasca Destinasi Maut Warga Kalsel. 2020. Accessed on: https://walhikalsel. or.id/lubang-pasca-tambang-destinasi-maut-wargakalsel/

Walhi. PT. MCM Ajukan PK, Meratus Memanggil Kita. 2021. Accessed on: https://www.walhi.or.id/pt-mcmajukan-pk-meratus-memanggil-kita

Yunianto Setiawan. Pengelolaan Tambang Batubara Berkelanjutan (Studi Kasus : Kota Samarinda) Kompasiana 23 Oktober 2010, https://www.kompasiana. com/yunianto_setiawan/550038eba33311 5372510247/ pengelolaan-tambang-batubara-berkelanjutan-studikasus-kota-samarinda 